\title{
Acoustic analysis of Korean trisyllabic words produced by English and Korean speakers
}

\author{
Jeong-Hwa Lee, Seok-Chae Rhee*
}

\begin{abstract}
The current study aimed to investigate the transfer of English word stress rules to the production of Korean trisyllabic words by L1 English learners of Korean. It compared English and Korean speakers' productions of seven Korean words from the corpus L2KSC (Rhee et al., 2005). To this end, it analyzed the syllable duration, intensity, and pitch. The results showed that English and Korean speakers' pronunciations differed markedly in duration and intensity. English learners produced word-initial syllables of greater intensity than Korean speakers, while Korean speakers produced word-final syllables of longer duration than English learners. However, these differences between the two speaker groups were not related to the expected L1 transfer. The tonal patterns produced by English and Korean speakers were similar, reflecting L1 English speakers' learning of the L2 Korean prosodic system.
\end{abstract}

Keywords: L1 transfer, L2 word production, Korean trisyllabic words, English and Korean

\section{Introduction}

First-language (L1) and second-language (L2) speech can be distinguished. Previous studies have revealed that listeners can identify the accentedness in L2 speech (Bent et al., 2016; Magen, 1998; Major, 2007; McCullough \& Clopper, 2016; Riney \& Flege, 1998). Factors such as age, gender, education, and length of residence affect L2 learners' degree of accentedness. Among various factors, learners' L1 plays a critical role in that the properties of L1 are transferred to L2 speech production. The L1 transfer is realized as non-native accents at the segmental and suprasegmental levels.

Lee et al. (2013) found that Chinese learners of Korean had more difficulty acquiring suprasegmental features than segmental ones. In their acquisition of L2 word accents, they were affected by their L1 intonation system which assigns lexical tones. Guion (2005) pointed out that prosodic factors have a greater impact than segmental ones on the perception of foreign accents. Previous studies (Guion et al., 2004; Guion, 2005; Wayland et al., 2006) investigated the acquisition of L2 English lexical stress patterns. They reported that the degree of L1 transfer differs with the speaker's linguistic background: differences in syllable structures and stress systems between the L1 and L2 affect the L2 stress learning. For example, L1 English groups showed a preference for coda clusters in stress assignment, while it was not found in Korean learners of English (Guion, 2005) as the Korean syllable system restricts coda clusters. Nevertheless, the studies evidenced the successful learning of English lexical stresses by learners of a phrasal pitch accent language (i.e., Korean) and a tone language (i.e., Thai) which do not have lexical stresses.

\footnotetext{
* Yonsei University, scrhee@yonsei.ac.kr, corresponding author

Received 28 February 2018; Revised 25 April 2018; Accepted 31 May 2018

(c) Copyright 2018 Korean Society of Speech Sciences. This is an Open-Access article distributed under the terms of the Creative Commons Attribution Non-Commercial License (http://creativecommons.org/licenses/by-nc/4.0) which permits unrestricted non-commercial use, distribution, and reproduction in any medium, provided the original work is properly cited.
} 
Early work has investigated the L1 transfer in the acquisition of L2 suprasegmental features that do not exist in the learners' L1 (Lee et al., 2013; Guion, 2005; Kim \& Baek, 2016; Lin et al., 2014; Ueda \& Kwon, 2014; Wayland et al., 2006; Yune, 2016). These studies revealed that linguistic similarities between the $\mathrm{L} 1$ and $\mathrm{L} 2$ facilitated the L2 acquisition, while differences between the two languages caused learning difficulties. It is widely known that the $\mathrm{L} 1$ can bring either a positive or negative transfer, as Ellis (2015) noted. Lin et al.'s study (2014) demonstrated the advantage of stress encoding in L2 English for Mandarin Chinese speakers. In English, there are minimal pairs of words between which the stress is the only difference. Similarly, in Mandarin, lexical tones play a role in discriminating between Chinese minimal pairs written in the same characters. Meanwhile, Yu and Adruski (2010) found that L1 English speakers preferred trochaic stresses while Chinese L2 learners preferred iambic stresses. They reported that the two groups used different acoustic cues for lexical stress due to their different language backgrounds.

The current study was designed to investigate the L1 transfer between languages with different prosodic systems. English and Korean are regarded as languages that differ widely in their rhythm production: as a stress-timed language English uses lexical stress, while the tonal patterns of accentual phrases determine the rhythm of the Korean language. Therefore, many studies have focused on the acquisition of the L2 English word stress (Guion et al., 2004; Guion, 2005; Lin et al., 2014; Wayland et al., 2006) or of the L2 Korean accentual phrase (In \& Seong, 2013; Kim \& Baek, 2016; Ueda \& Kwon, 2014; Yune, 2012; Yune, 2016). However, studies of the L2 Korean prosody have mainly focused on East Asian (i.e., Chinese and Japanese) learners of Korean. This study set out to examine the production of L2 Korean words by L1 English learners to determine whether it is affected by the L1 prosodic system. It was hypothesized that English learners tend to assign stress to their production of L2 Korean words. If so, there would be differences in the duration, intensity, and pitch of English and Korean speakers' productions. This study could make findings omitted by previous studies of L2 Korean accentual phrase, as they only analyzed the pitch between L1 and L2 Korean.

It has been noted that in English the assignment of lexical stress is influenced by the syllabic structure, i.e., the weight of the syllables in a word decides the stress patterns (Chomsky \& Halle, 1968; Hayes, 1980). Hayes (1980) introduced the notion of extrametricality in stress placement: in English nouns the final rime of the words does not receive a stress as it is considered extrametrical. The rule stated that the lexical stress is assigned to the penult if it is heavy. On the other hand, if the penult is light the antepenult receives the stress. Acoustically, the stressed syllable is recognized by longer duration, greater intensity, and higher pitch.

As a phrasal pitch accent language, Korean does not have lexical stresses. In Korean, an accentual phrase (AP) realized as tonal patterns forms a prosodic level in Korean. In the Seoul dialect (i.e., standard Korean), the underlying tonal pattern is THLH when the AP has more than four syllables. The first syllable of the AP begins with either an $\mathrm{H}$ or L tone, as determined by the laryngeal feature of the phrase-initial segment (Jun, 1998). Previous studies on the acquisition of the L2 Korean AP have mainly investigated APs within the boundary of an intonation phrase (IP) realized as a phrase or sentence (In \& Seong, 2013; Kim \& Baek, 2016; Yune, 2012; Yune, 2016). On the other hand, Lee et al. (2013) compared the

productions of Korean words by L1 Chinese learners of Korean and by native Korean speakers to investigate the Korean accents at the word level. In that study, the participants read the target words without context. Similarly, the current study examines Korean words produced by English and Korean speakers to determine whether transfer of the English word stress rules occurs.

\section{Method}

The data were taken from the L2KSC (Speech Corpus for Korean as a Foreign Language) (Rhee et al., 2005). It is the L2 Korean speech corpus built by Yonsei University, Korea. The corpus consists of productions of Korean by 357 adult speakers from 29 countries including Korea. The Korean speakers are natives from Seoul and the Gyeong-gi Province. All the participants recorded L1 words and various types of L2 Korean speech (words, non-words, sentences, a story, and spontaneous speech). Among these, instances of seven trisyllabic nouns were selected for the study. A total of 59 English learners and 51 Korean speakers recorded the words without context. Although some were compounds (apchima, gesipan, ahopsi, choroksaek, sinmunro), none of the words had spacing between the elements.

To identify the influence of the syllable weights, the target words were categorized into two groups according to the weights of the syllables: one group comprised words expected to be assigned stress on the antepenult by English learners of Korean, while the other comprised words expected to be assigned stress on the penult. None of them had the same syllabic structure, and the spelling of the words showed the weight of the syllables visually.

(1)

\begin{tabular}{|c|c|c|}
\hline abeoji (i.e., father) & /a.bs.dzii/ & $\mathrm{VCV} C \mathrm{C}$ \\
\hline apchima (i.e., apron) & /ab.ts ${ }^{\mathrm{jh}} \mathrm{i} . \mathrm{ma} /$ & $\mathrm{VCCV} \mathrm{CV}$ \\
\hline gesipan (i.e., notic & /ge.z $z^{h} \cdot p^{h} a n /$ & CV CV CVC \\
\hline at & $/ \mathrm{d}^{\mathrm{j}} \Lambda \mathrm{d} \cdot \mathrm{ka} . \mathrm{lag} /$ & $\mathrm{CVC} C \mathrm{CV} C$ \\
\hline
\end{tabular}

(2) $\begin{array}{lll}\text { ahopsi (i.e., nine o'clock) } & / \text { a.hob. } z^{\mathrm{h}} \mathrm{i} / & \mathrm{V} \mathrm{CVC} \mathrm{CV} \\ \text { choroksaek (i.e., green) } & / \mathrm{t}^{\mathrm{jh}} \mathrm{o} \cdot \log \cdot \mathrm{z}^{\mathrm{h}} \varepsilon \mathrm{g} / & \mathrm{CV} \mathrm{CVC} \mathrm{CVC} \\ \text { sinmunro (i.e., Sinmun street) } & / \mathrm{z}^{\mathrm{h}} \text { in.mun.no/ } & \text { CVC CVC CV }\end{array}$

The acoustic analysis was conducted with the sound analyzing program Praat (Boersma \& Weenink, 2016; version 6.0.18). The syllable durations of the words were measured by dragging and selecting the vowel parts of the spectrogram. To measure the pitch and intensity, the relevant program shortcuts were used (F5 for Get pitch, F8 for Get intensity). Speakers' mispronunciations were excluded from the analysis. Some speakers were found to have pronounced trisyllabic words as if they were disyllabic: some syllables including fricatives had no vowels on the spectrogram. The following table shows the number of speakers whose productions of the Korean words were included in the analysis (see $<$ Table $1>$ ).

$\mathrm{R}$ was used for the statistical analysis ( $\mathrm{R}$ Core Team, 2017; version 3.4.3). A two sample t-test was adopted to compare the means of the syllable duration, intensity, and pitch produced by the English and Korean speakers. An independent or Welch two sample t-test was used according to the p-value of the Shapiro-Wilk normality test and the $\mathrm{F}$ test. 
Table 1. Information of the participants

\begin{tabular}{l|c|c|c|c|c|c}
\hline & \multicolumn{3}{|c|}{ English } & \multicolumn{3}{c}{ Korean } \\
\hline & male & female & total & male & female & total \\
\hline abeoji & 28 & 23 & 51 & 26 & 25 & 51 \\
\hline apchima & 26 & 25 & 51 & 14 & 24 & 38 \\
\hline gesipan & 25 & 23 & 48 & 13 & 20 & 33 \\
\hline jeotgarak & 23 & 24 & 47 & 19 & 25 & 44 \\
\hline ahopsi & 26 & 23 & 49 & 26 & 25 & 51 \\
\hline choroksaek & 27 & 21 & 48 & 23 & 25 & 48 \\
\hline sinmunro & 31 & 20 & 51 & 11 & 17 & 28 \\
\hline
\end{tabular}

\section{Results}

The $<$ Table $2>$ shows that L1 English speakers did not produce the antepenults of the longest duration when they produced L2 Korean words with light penults.

Table 2. Means and standard deviations of duration (s)

\begin{tabular}{|c|c|c|c|c|c|}
\hline & & \multicolumn{2}{|c|}{ English } & \multicolumn{2}{|c|}{ Korean } \\
\hline & & M & SD & M & SD \\
\hline \multirow{3}{*}{ abeoji } & A & .094 & .032 & .082 & .018 \\
\hline & $\mathrm{P}$ & .112 & .029 & .119 & .016 \\
\hline & $\mathrm{F}$ & .131 & .059 & .146 & .039 \\
\hline \multirow{3}{*}{ apchima } & A & .068 & .023 & .053 & .014 \\
\hline & $\mathrm{P}$ & .082 & .064 & .052 & .018 \\
\hline & $\mathrm{F}$ & .113 & .040 & .154 & .032 \\
\hline \multirow{3}{*}{ gesipan } & A & .102 & .047 & .083 & .021 \\
\hline & $\mathrm{P}$ & .065 & .057 & .039 & .012 \\
\hline & $\mathrm{F}$ & .110 & .038 & .126 & .024 \\
\hline \multirow{3}{*}{ jeotgarak } & A & .065 & .021 & .050 & .012 \\
\hline & $\mathrm{P}$ & .121 & .072 & .119 & .027 \\
\hline & $\mathrm{F}$ & .105 & .025 & .125 & .033 \\
\hline \multirow{3}{*}{ ahopsi } & $\mathrm{A}$ & .136 & .079 & .098 & .024 \\
\hline & $\mathrm{P}$ & .081 & .022 & .083 & .016 \\
\hline & $\mathrm{F}$ & .122 & .050 & .131 & .038 \\
\hline \multirow{3}{*}{ choroksaek } & A & .110 & .087 & .053 & .017 \\
\hline & $\mathrm{P}$ & .095 & .029 & .075 & .013 \\
\hline & $\mathrm{F}$ & .075 & .027 & .109 & .028 \\
\hline \multirow{3}{*}{ sinmunro } & A & .055 & .031 & .032 & .012 \\
\hline & $\mathrm{P}$ & .103 & .044 & .070 & .018 \\
\hline & $\mathrm{F}$ & .148 & .044 & .162 & .049 \\
\hline
\end{tabular}

A for antepenult, $\mathrm{P}$ for penult, $\mathrm{F}$ for the final syllable

The longest duration of the words is highlighted in bold.

Moreover, none of the Korean words with heavy penults that they produced showed the longest duration on the penults. Meanwhile, Korean speakers always showed the longest duration on the final syllables when they produced the L1 words in isolation.

Korean speakers produced the final syllables of jeotgarak $(\mathrm{p}=$ $.002)$ and those of choroksaek $(p=.000)$ significantly longer than English speakers (See $<$ Figure $1>$ ). The two words have different weights on the penults, but the same heavy weight on the final syllables. This could indicate that Korean speakers produced longer duration on the word-final syllables than English speakers when the final syllables of the words had a heavy weight. However, no significance was found in the production of the word gesipan.

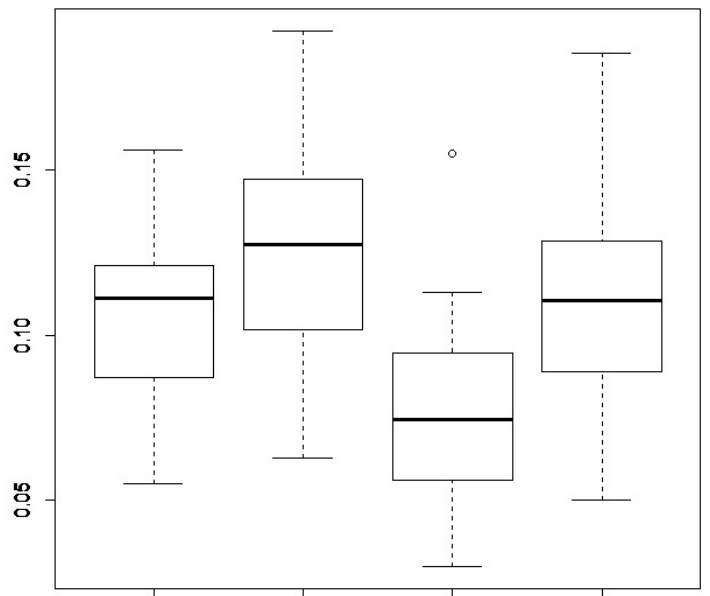

JeotgarakE JeotgarakK ChoroksaekE ChoroksaekK

Figure 1. The duration (s) on the final syllable of jeotgarak and choroksaek (E for English, K for Korean).

The $<$ Table $3>$ shows that English learners of Korean produced antepenults of the greatest intensity in the words abeoji, apchima, and gesipan. Their productions of the three words matched the predictions from the L1 word stress rules. However, English speakers' productions of intensity in the other four words did not reveal the transfer of the English stress system. Korean speakers placed the greatest intensity on the antepenults (apchima, gesipan, ahopsi) or the penults (abeoji, jeotgarak, choroksaek, sinmunro); none of the words' final syllables received the greatest intensity. The results were not related to the syllable weights of the penults.

Table 3. Means and standard deviations of intensity (dB)

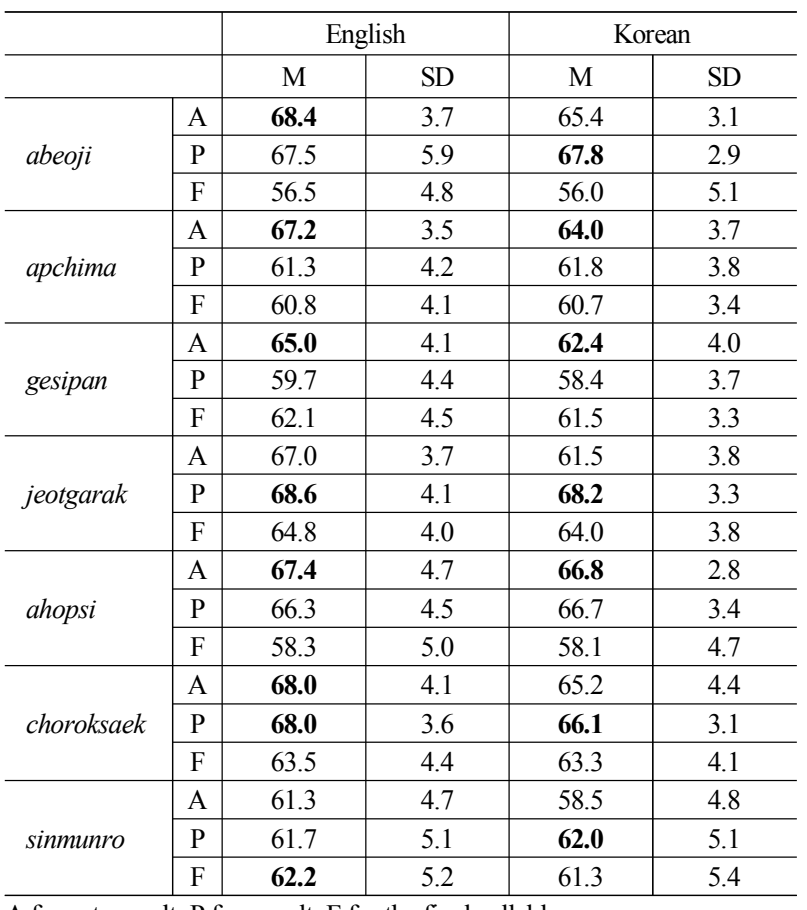

A for antepenult, $\mathrm{P}$ for penult, $\mathrm{F}$ for the final syllable

The greatest intensity of the words is highlighted in bold. 
Except in the word ahopsi, English and Korean speakers showed significant differences in intensity (see $<$ Figure $2>$ ): abeoji $(\mathrm{p}=$ $.000)$, apchima $(\mathrm{p}=.000)$, gesipan $(\mathrm{p}=.005)$, jeotgarak $(\mathrm{p}=.000)$, choroksaek $(\mathrm{p}=.002)$, sinmunro $(\mathrm{p}=.014)$. All the results showed significant differences for the antepenult position.
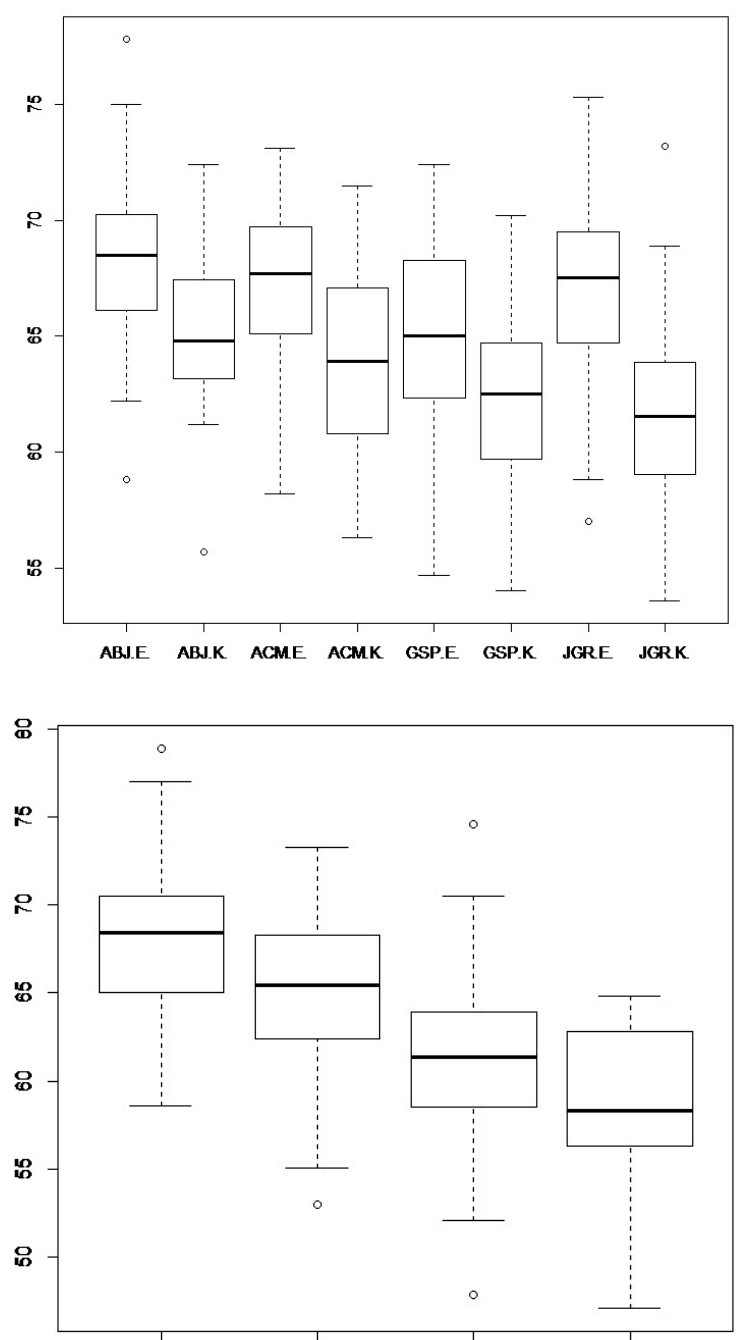

ChoroksaekE ChoroksaekK Sinmunno.E Sinmuno.K

Figure 2. The intensity $(\mathrm{dB})$ on the antepenult of abeoji, apchima, gesipan, jeotgarak, choroksaek, and sinmunro (E for English, K for Korean).

There was no syllable pitch significance found in the English and Korean speakers' productions of the seven Korean trisyllabic words. It was revealed that the tonal patterns of the words produced by the English speakers were similar to those produced by the Korean speakers. The two speaker groups showed a similar rising and falling pitch across the three syllables (see $<$ Figure $3>$ ). For the words abeoji, apchima, gesipan, and ahopsi, both English and Korean speakers had the highest pitch on the second syllables, while it was the highest on the first syllables in the words choroksaek and sinmunro (see $<$ Table $4>$ ).
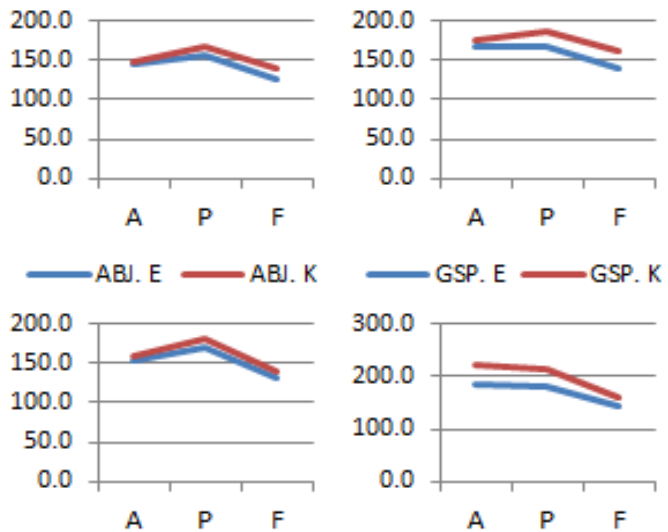

AHS. E

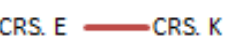

Figure 3. The mean pitch tracks $(\mathrm{Hz})$ of abeoji, gesipan, ahopsi, and choroksaek (E for English, $\mathrm{K}$ for Korean, A for antepenult, $\mathrm{P}$ for penult, $\mathrm{F}$ for the final syllable).

Table 4. Means and standard deviations of pitch $(\mathrm{Hz})$

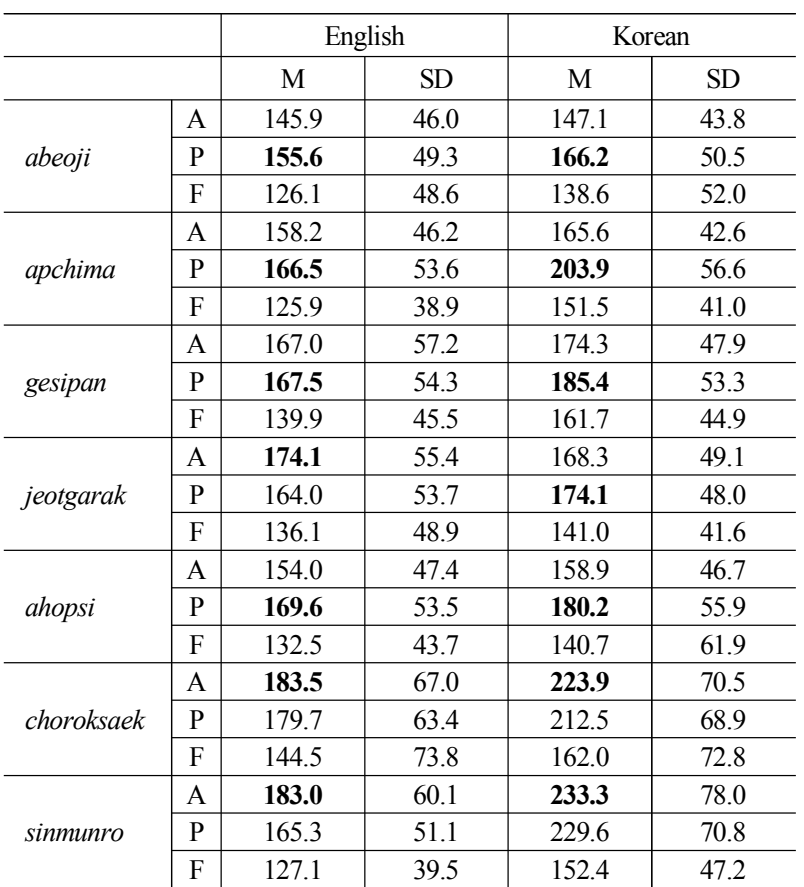

A for antepenult, $\mathrm{P}$ for penult, $\mathrm{F}$ for the final syllable

The highest pitch of the words is highlighted in bold.

\section{Discussion}

This study investigated English and Korean speakers' productions of Korean trisyllabic words to test the hypothesis that English learners of Korean may be influenced by their L1 word stress rules. L1 English speakers were expected to be sensitive to the weight of a penult. The syllable duration, intensity, and pitch of the target words were measured to compare the English and Korean speakers' productions.

Overall, the results on the syllable duration, intensity, and pitch did not show the expected L1 transfer. In the English speakers' productions of the L2 Korean words, the duration, intensity and pitch were not related to the prediction of the English lexical stress 
rules. Regarding the pitch, the tonal patterns of the Korean words produced by English speakers were similar to those of Korean speakers indicating that English learners of Korean learned the Korean prosodic system successfully. The results on syllable pitch reflected the prosodic characteristics of Korean which is a phrasal pitch accent language.

It has been noted that the differences between the L1 and L2 bring learning difficulties and the properties of $\mathrm{L} 1$ can be transferred to the L2. This account of language distance was supported by the Contrastive Analysis Hypothesis (CAH) (Lado, 1957), and a large body of studies on L1 transfer has focused on comparisons of L1 and L2. However, the CAH failed to explain what is transferred and what is not. Eckman (1977)'s Markedness Differential Hypothesis emphasized the role of language universals and stated that the degree of the transfer could be determined by typological markedness. Jun (2005) proposed a model of prosodic typology that included an analysis of 21 languages in the world. The only prosodic property shared by the languages was an intonation phrase (IP) which may be regarded as an unmarked property. Considering that the target words in this study could be regarded as IPs, the markedness universals could account for the L1 English speakers' successful learning of the Korean pitch accent.

Regardless of the L1 transfer, the results of the study revealed that English learners of Korean produced the word-initial syllables of greater intensity than Korean speakers. Moreover, the duration differed markedly between English and Korean speakers. Korean speakers always showed the longest word-final syllable duration when they produced the L1 words. They produced word-final syllables of longer duration than the English speakers when the weights of the syllables were heavy. Guion (2005) reported that the exposure to different types of prosodic systems affected Korean learners' non-nativelike knowledge of L2 English stress patterns. Similarly, the different duration and intensity produced by English and Korean speakers may result from different exposures. Further research is needed to shed light on this.

\section{References}

Bent, T., Atagi E., Akbik A., \& Bonifield, E. (2016). Classification of regional dialects, international dialects, and nonnative accents. Journal of Phonetics, 58, 104-117.

Boersma, P. \& Weenink, D. (2016). Praat: doing phonetics by computer [Computer program]. Version 6.0.18, retrieved from http://www.praat.org/ on 20 January 2018.

Chomsky, N., \& Halle, M. (1968). The sound pattern of English. NY: Harper \& Row.

Eckman, F. R. (1977). Markedness and the contrastive analysis hypothesis. Language Learning, 27(2), 315-330.

Ellis, R. (2015). Understanding second language acquisition (2nd ed.). Oxford: Oxford University Press.

Guion, S. G. (2005). Knowledge of English word stress patterns in early and late Korean-English bilinguals. Studies in Second Language Acquisition, 27, 503-533.

Guion, S. G., Harada, T., \& Clark, J. J. (2004). Early and late Spanish-English bilinguals' acquisition of English word stress patterns. Bilingualism: Language and Cognition, 7(3), 207-226.

Hayes, B. P. (1980). A metrical theory of stress rules. Doctoral Dissertation. Massachusetts Institute of Technology, USA.

In, J., \& Seong, C. (2013). Characteristics of AP tonal patterns \& slopes produced by Chinese learners of Korean. Phonetics and Speech Sciences, 5(3), 47-54. (인지영·성철재. (2013). 중국인 학습자의 한국어 강세구 성조패턴과 기울기 특성. 말소리와 음성과학, 5(3), 47-54.)

Jun, S.-A. (1998). The accentual phrase in the Korean prosodic hierarchy. Phonology, 15, 189-226.

Jun, S.-A. (2005) Prosodic typology. In Jun, S.-A. (Ed.), Prosodic typology: The phonology of intonation and phrasing (pp. 430-458). Oxford: Oxford University Press.

Kim, T.-K., \& Baek, G.-M. (2016). Accentual phrase realization in second language acquisition: The case of Korean-learning Chinese. The Korean Language and Literature, 68, 93-114. (김 태경·백경미. (2016). 중국인 학습자의 한국어 습득 과정에 나 타난 강세구 실현 양상 연구. 우리말글, 68, 93-114.)

Lado, R. (1957). Linguistics across cultures: Applied linguistics for language teachers. Ann Arbor: University of Michigan Press.

Lee, K.-J., Choi, S.-H., \& Choi, C.-H. (2013). A comparison of Korean word stress patterns of different lengths between Korean students and Chinese students in Korea. Journal of Speech-Language \& Hearing Disorders, 22(4), 87-104. (이경재. 최성희·최철희. (2013). 중국인 유학생과 한국인 대학생의 단 어 음절 수에 따른 한국어 단어 강세 비교. 언어치료연구, 22(4), 87-104.)

Lin, C. Y., Wang, M., Idsardi, W. J., \& Xu, Y. (2014). Stress processing in Mandarin and Korean second language learners of English. Bilingualism: Language and Cognition, 17(2), 316-346.

Magen, H. S. (1998). The perception of foreign-accented speech. Journal of Phonetics, 26, 381-400.

Major, R. (2007). Identifying a foreign accent in an unfamiliar language. Studies in Second Language Acquisition, 29, 539-556.

McCullough, E. A., \& Clopper, C. G. (2016). Perceptual subcategories within non-native English. Journal of Phonetics, 55, 19-37.

R Core Team (2017). R: A language and environment for statistical computing. R Foundation for Statistical Computing [Computer program]. Version 3.4.3, retrieved from http://www.R-project.org/ on 20 January 2018.

Rhee, S.-C., Kim, J.-A., Kim, T.-K., Jang, J-.W., \& Kim, J.-D. (2005). L2KSC: Speech Corpus for Korean as a Foreign Language. Yonsei University, Korea. (이석재·김정아·김태경·장재웅·김 종덕 (2005). 외국어로서의 한국어 음성코퍼스 $L 2 K S C$. 연세 대학교 산학협력단.)

Riney, T. J., \& Flege, J. E. (1998). Changes over time in global foreign accent and liquid identifiability and accuracy. Studies in Second Language Acquisition, 20, 213-243.

Ueda, A., \& Kwon, S.-M. (2014). Accent features of Tokyo speakers and Kansai speakers realized in speaking Korean words. Ehwaeomunnonjip, 34, 125-145. (우에다·권성미. (2014). 동경 방언 화자와 관서 방언 화자의 한국어 단어 발음에 실현되는 악센트의 특징. 이화어문논집, 34, 125-145.)

Wayland, R., Guion, S. G., Landfair, D., \& Li, B. (2006). Native Thai speakers' auquisition of English word stress patterns. Journal of Psycholinguistic Research, 35, 285-304.

Yu, V. Y., \& Andruski, J. E. (2010). A cross-language study of perception of lexical stress in English. Journal of Psycholinguistic Research, 39, 323-344.

Yune, Y. (2012). A study on the detection and the correction of prosodic errors produced by Chinese Korean-learners. Phonetics and Speech Sciences, 4(2), 51-59. (윤영숙. (2012). 중국인 학습 자들의 한국어 강세구 실현양상과 오류진단 및 교정방안 연 
구. 말소리와 음성과학, 4(2), 51-59.)

Yune, Y. (2016). Positive and negative transfer of first language in producing second language - Focusing on Japanese learners of Korean. Phonetics and Speech Sciences, 8(4), 71-78. (윤영숙. (2016). L2 억양에 나타나는 L1억양의 긍정적 전이와 부정적 전이 양상. 말소리와 음성과학, 8(4), 71-78.)

\section{- Jeong-Hwa Lee}

Department of English Language and Literature Yonsei University

50 Yonsei-ro, Seodaemun-gu

Seoul 03722, Korea

Tel: 02-2123-2300

Email: jeonghwalee@yonsei.ac.kr

Fields of interest: Phonetics, Phonology

- Seok-Chae Rhee corresponding author

Department of English Language and Literature Yonsei University

50 Yonsei-ro, Seodaemun-gu

Seoul 03722, Korea

Tel: 02-2123-4483

Email: scrhee@yonsei.ac.kr

Fields of interest: Phonetics, Phonology 